\title{
B-chromosomes in two Brazilian populations of Dendropsophus nanus (Anura, Hylidae)
}

\author{
Lilian R. Medeiros ${ }^{1}$, Denise C. Rossa-Feres ${ }^{2}$, Jorge $\mathrm{Jim}^{3}$ and Shirlei M. Recco-Pimentel ${ }^{1}$ \\ ${ }^{1}$ Universidade Estadual de Campinas, Instituto de Biologia, Departamento de Biologia Celular, \\ Campinas, SP, Brazil. \\ ${ }^{2}$ UNESP, Universidade Estadual Paulista, Instituto de Biociências, Letras e Ciências Exatas, \\ Departamento de Zoologia e Botânica, São José do Rio Preto, SP, Brazil. \\ ${ }^{3}$ UNESP, Universidade Estadual Paulista, Departamento de Zoologia, Botucatu, SP, Brazil.
}

\begin{abstract}
We report on the presence of B-chromosomes in two populations of Dendropsophus nanus (= Hyla nana Boulenger, 1889) from São Paulo State, Brazil. Such chromosomes were observed in 4 out of 43 specimens (9.3\%) and in 9 out of 15 specimens (60\%) from the municipalities of Nova Aliança and Botucatu, respectively. The karyotype $2 n=30+$ $1 \mathrm{~B}$ found in $D$. nanus was similar to that of other species with $2 \mathrm{n}=30$ chromosomes, except for the presence of an additional small telocentric chromosome. In one specimen from Botucatu, cells with one to three extra chromosomes were observed. These B-chromosomes appeared as univalent in meiosis I and did not bear a nucleolar organizer region or exhibit constitutive heterochromatin.
\end{abstract}

Key words: Anura, b-chromosome, cytogenetics, Dendropsophus, supernumerary chromosome.

Received: April 12, 2005; Accepted: October 10, 2005.

\section{Introduction}

B-Chromosomes are extra chromosomes that occur in animals and plants and are generally considered dispensable for normal development, since they have no apparent function (Jones and Rees, 1982). B-chromosomes have been found in approximately 15\% of living species (Beukeboom, 1994), and described in 26 species of salamanders and frogs (Green, 2004). As a rule, carriers of these chromosomes are phenotypically indistinguishable from those individuals without them (Clark and Wall, 1996). B-chromosomes bear no similarity to the autosomes, are inherited according to a non-Mendelian pattern, and occur as univalents in meiosis (Jones and Rees, 1982; Green, 1991, 2004).

The number of B-chromosomes can vary among populations of the same species, among individuals in a population and among cells in an individual. In the latter case, this variation results from anaphase lag, with subsequent elimination of B-chromosomes from some cells or tissues, or, alternatively, it is caused by mitotic non-disjunction, with sister chromatids migrating to the same pole (Clark and Wall, 1996).

Send correspondence to Shirlei M. Recco-Pimentel. Universidade Estadual de Campinas, Instituto de Biologia, Departamento de Biologia Celular, 13083-863 Campinas, SP, Brazil. E-mail: shirlei@unicamp.br.
Among vertebrates, one of the largest variations in the number of B-chromosomes has been described in Leiopelma hochstetteri, a frog endemic to New Zealand, in which individuals with up to 16 of these chromosomes have been observed (Green, 1988). This variation has been attributed to mitotic non-disjunction resulting from instability during cell division.

In Anura, B-chromosomes have been described in 10 species belonging to six families: Hylidae (Acris crepitans, Hypsiboas sp. aff. circundata) (Nur and Nevo, 1969; Baldissera et al., 1993), Leiopelmatidae (Leiopelma hochstetteri) (Green et al., 1987, 1993; Green, 1988, 2004; Sharbel et al., 1998), Discoglossidae (Discoglossus pictus) (Schmid et al., 1987), Pelobatidae (Scaphiopus hammondi) (Green, 1991), Ranidae (Amolops liangshanensis, Rana everetti, R. temporaria) (Ullerich, 1967; Schmid, 1978; Wu and Zhao, 1985; Kuramoto, 1989; Belcheva and Sofianidou, 1990), and Leptodactylidae (Megaelosia massarti, Gastrotheca espeletia) (Rosa et al., 2003; Schmid et al., 2002). Anuran B-chromosomes vary in size, in the amount of heterochromatin and repeated DNA sequences, and in number. Most B-chromosomes in anurans are derived from the A set of chromosomes in the corresponding species and have apparently undergone cumulative evolutionary changes since their formation (Green, 2004). 
Herein we describe the presence of B-chromosomes in specimens of Dendropsophus nanus (= Hyla nana Boulenger, 1889) from two populations collected at different sites in southeastern Brazil.

\section{Materials and Methods}

Forty-three specimens ( 40 males and 3 females) of $D$. nanus were collected in Nova Aliança $\left(22^{\circ} 11^{\prime} \mathrm{S}, 49^{\circ} 42^{\prime} \mathrm{W}\right)$, São Paulo State (SP), Brazil, from February through May 1998 and from October 1998 through May 1999, and 15 specimens (all males) were collected in Botucatu ( $22^{\circ} 53^{\prime} \mathrm{S}$, $\left.48^{\circ} 26^{\prime} \mathrm{W}\right)$, SP, Brazil, in November 2000.

The specimens were identified according to Medeiros et al. (2003), and were deposited in the "Prof. Adão José Cardoso" Museum of Natural History (ZUEC), of Universidade Estadual de Campinas, SP, Brazil, and in the Zoology Department (DSJRP) of Universidade Estadual Paulista, São José do Rio Preto, SP, Brazil, under the accession numbers ZUEC 11405 to 11412,11416 to 11418,11647 to 11677, 12242 to 12272 and DZSJRP 1111. The frogs were collected with the permission of the Brazilian Institute for the Environment and for Natural Renewable Resources (Instituto Brasileiro do Meio Ambiente e Recursos Renováveis - IBAMA - Proc. 02001.008876/01-83).

Chromosome preparations were obtained from intestinal and testicular cell suspensions, as described by
Schmid (1978) and Schmid et al. (1979) and analyzed after routine staining with a $10 \%$ Giemsa solution, C-banding (King, 1980), Ag-NOR staining (Howell and Black, 1980) and fluorescence in situ hybridization (FISH) (Viegas-Péquignot, 1992) with an rDNA probe. The FISH probe consisted of a recombinant HM123 plasmid containing a fragment of Xenopus laevis rDNA (Meunier-Rotival et al., 1979), which was biotin-labelled by nick translation reaction using a BioNick ${ }^{\mathrm{TM}}$ Labeling System (Invitrogen). The probe was detected using goat anti-biotin and fluorescein anti-goat IgG (Vector Laboratories). Analysis was done with an Olympus BX60 photomicroscope. The chromosomal nomenclature regarding the position of centromere followed the classification proposed by Green and Sessions (1991).

\section{Results}

The karyotype of 39 specimens of D. nanus from Nova Aliança and of five specimens from Botucatu showed $2 \mathrm{n}=30$ chromosomes (Figure 1A), as previously described for a population from Nova Aliança (Medeiros et al., 2003). However, in four males from Nova Aliança (ZUEC 11673, 11651, 11652 and DZSJRP 1111) and nine males from Botucatu (ZUEC 12242, 12245, 12246, 12247, 12249, $12251,12254,12256$ and 12261), the karyotype was $2 \mathrm{n}=31$ chromosomes (Table 1$)$. This karyotype differed

A.

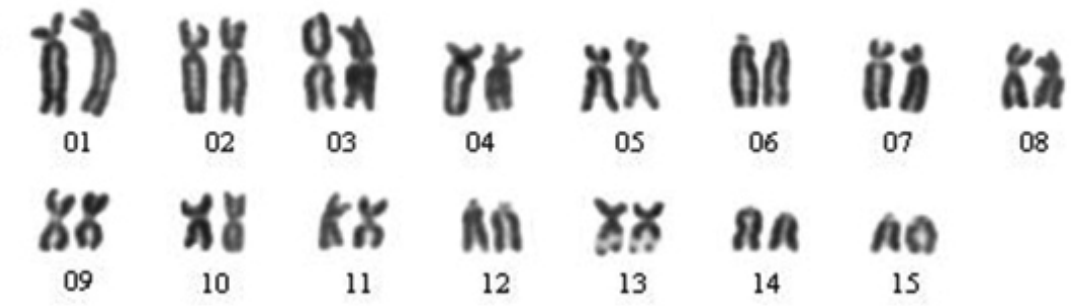

B.

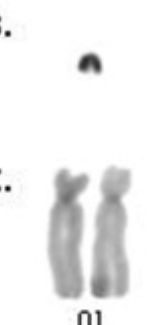

c.

B Chromosomes

D.

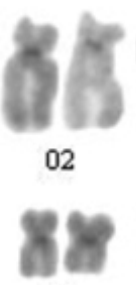

10

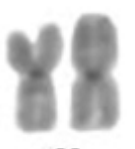

03

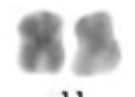

11

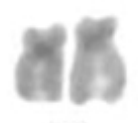

04

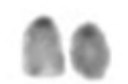

12

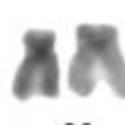

os

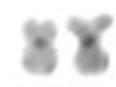

13

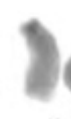

06
07

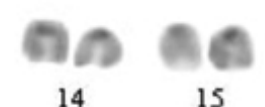

15
F.

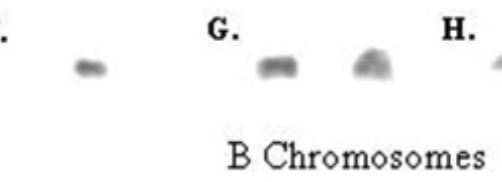

H.

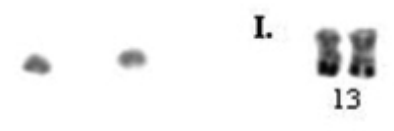

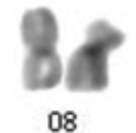

Figure 1 - Karyotype of D. nanus after Giemsa staining (A) and C-banding (E). One, two or three small telocentric B-chromosomes were observed in metaphases from some specimens after Giemsa staining (B-D) and C-banding (F-H). Ag-NORs were detected on chromosome pair $13(\mathrm{I})$. Bar $=5 \mu \mathrm{m}$. 
from that with $2 \mathrm{n}=30$ by the presence of an extra small telocentric chromosome (Figure 1B). In one specimen from Botucatu, we observed cells with $2 \mathrm{n}=30+1 \mathrm{~B}, 30+2 \mathrm{~B}$ and $30+3 \mathrm{~B}$ chromosomes (Figure 1B-D; Table 1). These additional chromosomes were all of the same size and morphology.

The small extra chromosome was observed in meiosis I metaphases that had 15 bivalents and one, two or three small univalents (Figure 2A-C). Hence, the B-chromosomes did not pair with the A-chromosomes. Individuals with $2 \mathrm{n}=30$ chromosomes had 15 bivalents, and no univalents were observed.

The two populations of D. nanus shared a common C-banding pattern characterized by small amounts of heterochromatin in the pericentromeric region of all chromosomes (Figure 1E), except for the extra chromosomes (Figure 1F-H), in which no C-bands were observed. These chromosomes did not bear a NOR, as demonstrated by Ag-NOR staining and/or FISH in four specimens with $2 \mathrm{n}=30+1 \mathrm{~B}$ chromosomes from Nova Aliança and in all specimens from Botucatu with $2 n=30+1 B$ and $2 n=30+1$ - 3B. Chromosome pair 13 was identified as the NORbearing chromosome in all specimens analyzed (Figures 1I and $3 \mathrm{~A}, \mathrm{~B})$.

\section{Discussion}

The extra chromosomes found in specimens of $D$. nanus with $2 \mathrm{n}=31$ and in the specimen from Botucatu that had cells with $2 n=31$ to $2 n=33$ chromosomes can be considered as B-chromosomes, since they showed some of the characteristics usually attributed to these chromosomes. This small extra element, which differs morphologically from autosomes, always occurs as a univalent in cells in metaphase I (reviewed in Jones and Rees, 1982).

Previous descriptions of the karyotype of D. nanus from other populations (Rabello, 1970; Bogart, 1973; Skuk and Langone, 1992) did not mention the presence of B-chromosomes.

Since individuals carrying B-chromosomes are generally indistinguishable from those without these chromosomes, the conclusion is that B-chromosomes must not carry genes with important phenotypic effects. However, the maintenance of B-chromosomes in certain populations has been taken as indicative of their role in conferring some advantage to transcriptional activity or to the genetic variability of the species, as pointed out by Belcheva and Sofianidou (1990), when describing B-chromosomes in Rana temporaria. Indeed, several studies have shown that some B-chromosome genes are expressed (Green, 1990; Jones, 1995; Covert, 1998; Camacho, 2000; Green, 2004), and their phenotypic influence may be dependent on the number of these chromosomes present in the cell, although this has not yet been documented for amphibians (Green, 1991). The deleterious effect can be a decrease in fertility (Hewitt et al., 1987) or an abnormal meiosis (Parker et al., 1981). An interesting case of B-chromosomes in amphibians involves Leiopelma hochstetteri (Anura), which may have up to 16 extra chromosomes. In this species, the B-chromosomes in the lampbrush state have small lateral loops indicating transcriptional activity, although lower than that of autosomes (Green et al., 1987; Green, 1988).

Table 1 - Museum accession numbers of specimens, sex, (locality of) collection site, number of metaphases analyzed and number of B-chromosomes per cell in Dendropsophus nanus.

\begin{tabular}{|c|c|c|c|c|c|c|c|}
\hline \multirow{2}{*}{$\begin{array}{l}\text { Specimens } \\
\text { (Museum accession } \\
\text { number) }\end{array}$} & \multirow[t]{2}{*}{ Sex } & \multirow[t]{2}{*}{$\begin{array}{l}\text { Collection site in the } \\
\text { State of São Paulo }\end{array}$} & \multicolumn{2}{|c|}{ Number of metaphases analyzed } & \multicolumn{2}{|c|}{$\begin{array}{c}\text { Number of metaphases with } \\
\text { B-chromosomes }\end{array}$} & \multirow[t]{2}{*}{$\begin{array}{c}\text { Number of } \\
\text { B-chromosomes/cell }\end{array}$} \\
\hline & & & Intestine & Testis & Intestine & Testis & \\
\hline ZUEC 11652 & M & Nova Aliança & 23 & 11 & 14 & 7 & 1 \\
\hline ZUEC 11673 & $\mathrm{M}$ & Nova Aliança & 12 & 8 & 5 & 6 & 1 \\
\hline \multirow[t]{3}{*}{ ZUEC 12242} & M & Botucatu & 28 & 39 & 9 & 10 & 1 \\
\hline & & & & & 6 & 9 & 2 \\
\hline & & & & & 5 & 12 & 3 \\
\hline ZUEC 12245 & M & Botucatu & 24 & 6 & 18 & 9 & 1 \\
\hline ZUEC 12246 & M & Botucatu & 14 & 12 & 12 & 8 & 1 \\
\hline ZUEC 12247 & M & Botucatu & 8 & 5 & 5 & 3 & 1 \\
\hline ZUEC 12251 & $\mathrm{M}$ & Botucatu & 12 & 10 & 8 & 8 & 1 \\
\hline ZUEC 12254 & $\mathrm{M}$ & Botucatu & 18 & 12 & 13 & 9 & 1 \\
\hline ZUEC 12256 & $\mathrm{M}$ & Botucatu & 28 & 14 & 23 & 9 & 1 \\
\hline ZUEC 12261 & M & Botucatu & 13 & 8 & 7 & 6 & 1 \\
\hline
\end{tabular}

ZUEC = Museu de História Natural "Professor Adão José Cardoso", Universidade Estadual de Campinas, SP, Brazil.

DZSJRP = Departamento de Zoologia, Universidade Estadual Paulista, São José do Rio Preto, SP, Brazil. 
The B-chromosomes of $D$. nanus did not bear a NOR, as demonstrated by silver staining and FISH). Ribosomal genes are rarely present on B-chromosomes, and in Anura they have been detected only in Scaphiopus hammondi (Green, 1988) and Gastrotheca espeletia (Schmid et al., 2002). In the former species, the NOR contributed to increase the number of nucleoli in the cell, indicating that B-chromosomes can carry functional genes of great importance (Green, 1991).

A.

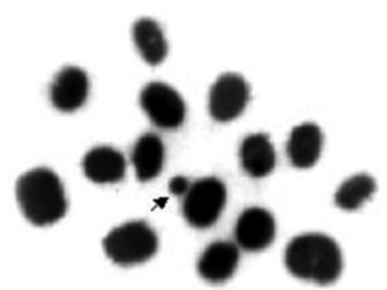

B.

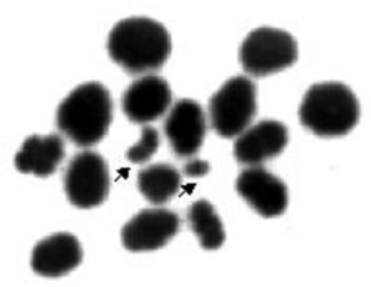

c.

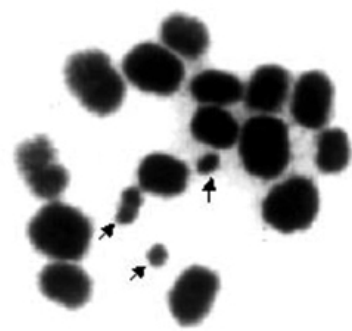

Figure 2 - D. nanus metaphases I with 15 bivalents and one (A), two (B) and three (C) small univalent B-chromosomes, after Giemsa staining. Bar $=5 \mu \mathrm{m}$.
Various mechanisms have been proposed to explain the origin and maintenance of B-chromosomes. Traditionally, these chromosomes are believed to be derived from autosomes (Jones and Rees, 1982). Since pairing or chiasmata between B-chromosomes and A-chromosomes are not observed in meiosis, it is probable that the original homology between them was rapidly lost. Modifications in the structure and in the pairing behavior during meiosis would prevent association with the ancestral A-chromosomes (Camacho et al., 2000). Interestingly, in the anuran Leiopelma hochstetteri, the B-chromosomes are most probably derived from the sex chromosome (Green, 2004), a conclusion supported by the sequence homology between the B-chromosomes and the univalent W chromosome (Sharbel et al., 1998; Green, 2004).

Heterochromatization is a common process in the differentiation of B-chromosomes, since many are completely heterochromatic in numerous species (Venere et al., 1999). Although the heterochromatic condition of B-chromosomes is not a general pattern, these chromosomes may originate from centromeric fragments, but this hypothesis has received little support (Green et al., 1987; Camacho et al., 2000). This process of B-chromosome differentiation is not applicable to $D$. nanus, since in this species the B-chromosomes showed no heterochromatic band, and hence their derivation must have involved different mechanisms.

Another possibility to explain the origin of B-chromosomes is that they derive from A-chromosomes of closely related species through interspecific hybridization, as suggested for hybrid species of the fish Poecilia formosa (Schartl et al., 1995) and of the wasp genus Nasonia (McAllister and Werren, 1997). Dendropsophus sanborni Schmidt, 1944, is morphologically (Cei, 1980; Medeiros et al., 2003) and ecologically (Rossa-Ferres and Jim, 2001) very similar to $D$. nanus, and both belong to the same intrageneric group (Frost, 2004). Considering their great similarity and syntopic occurrence in several localities
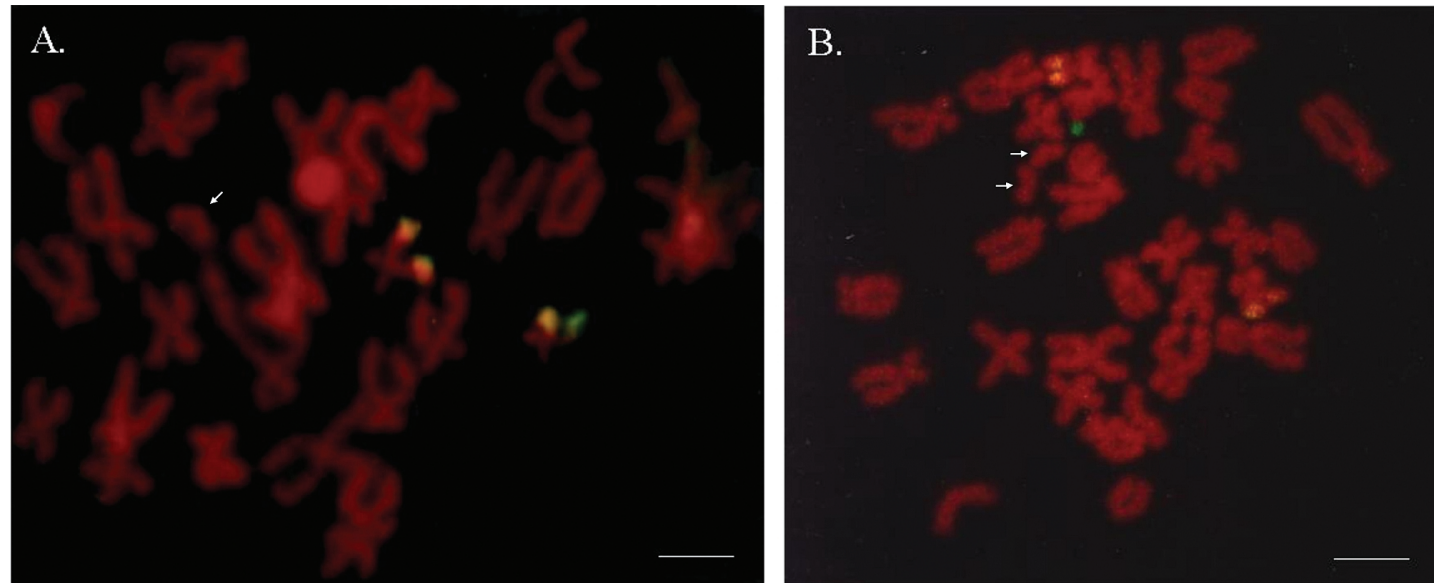

Figure 3 - D. nanus mitotic metaphases with one (A) and two (B) B-chromosomes (arrows) after fluorescence in situ hybridization to Xenopus laevis rDNA probe. No FISH signals were detected on the B-chromosomes. Bar $=5 \mu \mathrm{m}$. 
(Langone and Basso, 1987), we cannot rule out the hypothesis of interspecific hybridization in the origin of D. nanus karyotypes with B-chromosomes.

\section{Acknowledgments}

The authors thank Marcelo Menin and Silvio César de Almeida for help with the field work, Klélia A. Carvalho for technical assistance and Dr. Luciana B. Lourenço for assistance in FISH experiments. This work was supported by Fundação de Amparo à Pesquisa do Estado de São Paulo (FAPESP, proc. 00/11031-4) and Conselho Nacional de Desenvolvimento Científico e Tecnológico (CNPq).

\section{References}

Baldissera Jr FA, Oliveira PSL and Kasahara S (1993) Cytogenetics of four Brazilian Hyla species (Amphibia-Anura) and description of a case with a supernumerary chromosome. Rev Bras Genet 16:335-345.

Belcheva RG and Sofianidou TS (1990) Karyological investigation of the brown frogs species (Anura, Ranidae) from Bulgaria and Greece. In: Cytogenetics of Amphibians and Reptiles. Birkhauser-Verlag, Basel, pp 141-146.

Beukeboom LW (1994) Bewildering Bs: An impression of the $1^{\text {st }}$ B chromosome conference. Heredity 73:328-336.

Bogart JP (1973) Evolution of anuran karyotypes. In: VIAL, JL (ed) Evolutionary Biology of Anurans. University of Missouri Press, Columbia, pp 337-349.

Camacho JPM, Sharbel TF and Beukeboom LW (2000) B-chromosome evolution. Phil Trans R Soc Lond 335:163-178.

Cei JM (1980) Amphibians of Argentina. Monitore Zoologico Italiano (NS). Monografia 2:1-609.

Clark MS and Wall WJ (1996). Chromosome form and function. In: Chromosomes: the Complex Code. Ed. Chapman and Hall, London, pp 61-65.

Covert SF (1998) Supernumerary chromosomes in filamentous fungi. Curr Genet 33:311-319.

Frost DR (2004) Amphibian species of the world: An online reference. Version 3.0 (22 August 2004) Eletronic Database, http://research.amnh.org/herpetology/amphibia/index.html. American Museum of Natural History, New York, USA.

Green DM (1988) Cytogenetics of the endemic New Zealand frog, Leiopelma hochsteteri: Extraordinary supernumerary chromosome variation and a unique sex-chromosome system. Chromosoma 97:55-70.

Green DM (1990) Miller's ratchet and the evolution of supernumerary chromosomes. Genome 33:818-824.

Green DM (1991) Supernumerary chromosomes in amphibians. In: Green DM and Sessions SK (eds) Amphibian Cytogenetics and Evolution. Academic Press, San Diego, pp 333-358.

Green DM and Sessions SK (1991) Nomenclature of chromosomes. In: Green DM and Sessions SK (eds) Amphibian Cytogenetics and Evolution. Academic Press, San Diego, pp 431-432.

Green DM (2004) Structure and evolution of B chromosomes in amphibians. Cytogenet. Genome Res 106:235-242.

Green DM, Kezer J and Nussbaum RA (1987) Supernumerary chromosome variation and heterochromatin distribution in the endemic New Zealand frog, Leiopelma hochstetteri. Chromosoma 95:339-344.

Green DM, Zeyl CW and Sharbel TF (1993) The evolution of hypervariable sex and supernumerary chromosomes in the relict New Zealand frog. Leiopelma hochstetteri. J Evol Biol 6:417-441.

Hewitt GM, East TM and Shaw MW (1987) Sperm dysfunction produced by B-chromosomes in the grasshopper Myrmeleo Otettix maculatus. Heredity 58:59-68.

Howell WM and Black DA (1980) Controlled silver staining of nucleolus organizer regions with a protective colloidal developer: A 1-step method. Experientia 36:1014-1015.

Jones RN (1995) Tansley review n. 85. B chromosomes in plants. New Phytol 131:411-434.

Jones RN and Rees H (1982) B-Chromosomes. Academic Press, London, $266 \mathrm{pp}$.

King M (1980) C-banding studies in Australian hylid frogs: Secondary constriction structure and the concept of euchromatin transformation. Chromosoma 80:191-207.

Kuramoto M (1989) Karyologycal studies on some Philippine frogs. In: Matsui M, Kikida T and Goris RC (eds) Current Herpetology in East Asia. Herpetological Society of Japan, Kyoto, pp 115-121.

Langone JA and Basso NG (1987) Distribucion geografica y sinonima de Hyla nana Boulenger, 1889 y Hyla sanborni Schmidt, 1944 (Anura, Hylidae) y observaciones sobre formas afines. Com Zool Mus Hist Nat Montevideo 164:1-17.

McAllister BF and Werren JH (1997) Hybrid origin of a B chromosome (PSR) in the parasitic wasp Nasonia vitripennis. Chromosoma 106:243-253.

Medeiros LR, Rossa-Feres DC and Recco-Pimentel SM (2003) Chromosomal differentiation of Hyla nana and Hyla sanborni (Anura, Hylidae) with a description of NOR polymorphism in H. nana. J Heredity 94:149-154.

Meunier-Rotival M, Cortadas J and Macaya G (1979) Isolation and organization of calf ribosomal DNA. Nucleic Acids Res 6:2109-2123.

Nur U and Nevo E (1969) Supernumerary chromosome in the cricket frog, Acris crepitans. Caryologia 22:97-102.

Parker JS, Ainsworth CC and Taylor S (1981) The B-chromosome system of Hypochoeris maculata II. B-effects on meiotic A-chromosome behaviour. Chromosoma 67:123-143.

Rabello MN (1970) Chromosomal studies in Brazilian anurans. Caryologia 23:45-59.

Rosa C, Aguiar-Jr O, Giaretta AA and Recco-Pimentel SM (2003) Karyotypic variation in the genus Megaelosia (Anura, Hylodinae) with the first description of a B-chromosome in a leptodactylid frog. Copeia 2003:166-174.

Rossa-Feres DC and Jim J (2001) Similaridade do sítio de vocalização em uma comunidade de anfíbios anuros na região noroeste do Estado de São Paulo, Brasil. Rev Bras Zool 18:439-454.

Schartl M, Nanda I, Schlupp I, Wilde B, Epplen JT, Schmidt M and Parzefall J (1995) Incorporation of subgenomic amounts of DNA as compensation for mutational load in a gynogenetic fish. Nature 373:68-61.

Schmid M (1978) Chromosome banding in Amphibia. I. Constitutive heterochromatin and nucleolus organizer regions in Bufo and Hyla. Chromosoma 66:361-388. 
Schmid M, Orlet J and Klett C (1979) Chromosome banding in Amphibia III. Sex chromosomes in Triturus. Chromosoma 71:29-55.

Schmid M, Vitelli L and Batistoni R (1987) Chromosome banding in Amphibia XI. Constitutive heterochromatin, nucleolus organizer regions $18 \mathrm{~S}+28 \mathrm{~S}$ and $5 \mathrm{~S}$ ribosomal RNA genes in Ascaphidae, Pipidae, Discoglossidae and Pelobatidae. Chromosoma 95:271-284.

Schmid M, Zieglr CG, Steinlein C, Nanda I and Haaf T (2002) The B chromosomes of Gastrotheca espeletia (Anura, Hylidae). Cytogenet. Genome Res 97:205-218.

Sharbel TF, Green DM and Houben A (1998) B chromosome origin in the endemic New Zealand frog Leiopelma hochstetteri through sex chromosome devolution. Genome 41:14-22.
Skuk G and Langone JA (1992) Los cromosomas de cuatro especies del género Hyla (Anura, Hylidae) com número diploide de $2 n=30$. Acta Zool Lilloana 41:165-171.

Ullerich FH (1967) Weitere Untersuchungen über Chromosomenverhältnisse und DNS-Gehalt bei Anuren (Amphibia). Chromosoma 21:345-368.

Venere PC, Miyazawa CS and Galetti Jr PM (1999) New cases of supernumerary chromosome in characiform fishes. Gen Mol Biol 22:345-349.

Viegas-Péquignot E (1992) In situ hybridization to chromosomes with biotinylated probes. In: Willernson D (ed) In situ Hybridization: A Practical Approach. Oxford University Press-IRL Press, Oxford, pp 137-158.

Wu GF and Zhao E (1985) Preliminary studies on karyotypes of the genus Amolops of the Hengduan mountains. Acta Herpetol Sinica 4:276-282.

Associate Editor: Yatiyo Yonenaga-Yassuda 